\title{
Legal approach to marine accidents: a comparative research between Turkish and international perspectives
}

\author{
Nil Kula Degirmenci ${ }^{1 . *}$ \\ ${ }^{1}$ Izmir Dokuz Eylul University, Maritime Faculty, Department of Maritime Business Administration, \\ Izmir, Turkey
}

\begin{abstract}
The importance of prevention of marine accidents increases parallel to the technological improvements in maritime transportation and the rise of sensitiveness to environmental protection. Legal approach to marine accidents can be gathered under three important topics as follows: legal approach to general average, legal approach to collision and legal approach to salvage. The international perspective on the issue has been shaped through international conventions and advisory rules, as applied in the field of general average, and some of their modernized amendments. Turkey which is one of the most important countries in maritime transportation especially as a result of its geographical position, on the one hand aims to protect its existing legal regime to prevent the occurrence of marine accidents and on the other hand follows the updated legal developments on the issue. In the study, it is aimed to point the important facts of general average, salvage and collision and analyze the Turkish and international perspectives comparatively. Thus the success in ensuring uniformity which is targeted through the international studies on these issues is tried to be measured for the Turkey example.
\end{abstract}

\section{Introduction}

With the increased frequency of shipping activities, navigation safety has become a major concern especially when economic losses, human casualties and environmental issues are considered [1]. Investigations into the causes of shipping accidents show that over $30 \%$ of the accidents are caused by poor weather, and an additional $25 \%$ remain completely unexplained [2]. On the other hand the need for qualified seamen is one of the major problems in improving safety in the shipping industry [3].

About $63 \%$ of the world's shipping accidents are recurrent - they occur to ships that have already experienced at least one prior accident [4]. Therefore, reducing recurrent accidents or adopting a legal framework to determine the applications upon the occurrence of marine accident can contribute significantly to maritime safety. Thus, in the study, legal approach to marine accidents has been analyzed in terms of general average, collision and

${ }^{*}$ Corresponding author: nilkuladegirmenci@gmail.com 
salvage through the framework of international conventions and domestic legislation of Turkey.

\section{Legal Approach to Marine Accidents}

In this part of the study, legal approach to marine accidents has been analyzed in terms of general average, collision and salvage.

\subsection{Legal Approach to General Average}

Because the marine adventure is viewed as a joint project risk of the parties including the ship owner, master, crew, and cargo owners, involved, all are deemed as sharing the risk [5]. Due to the complexity of activities which can generate cargo surveys in respect of transport, maritime ships can be in such situations that will not allow carrying out activities onboard under normal conditions, leading to damages to the ships or carried cargo, thus entailing litigations between participants in such transport [6]. A general average act usually comes into play when a part of the cargo is jettisoned, by order of the ship's master, in order to save the ship, the remaining cargo, and all who are in the ship. General average is one of the most historic issues governed under maritime law. There are no international conventions that govern general average through a mandatory approach, however Comité Maritime International (CMI) has adopted several groups of rules, namely York Antwerp Rules (YAR), which are frequently adopted and applied by most countries all over the world, even though they have advisory characteristics. All the standard forms of contracts of affreightment and bills of lading refer to the application of YAR. These rules have been renewed at certain periods of time, such as 1924, 1950, 1974, 1990, 1994, 2004 and the latest, 2016.

The substance of the YAR - in some cases the actual text - has been incorporated into the law of many countries. Unless otherwise agreed by the parties, Turkish Commercial Code (TCC) directly refers to the application of the updated version of YAR for the general average adjustment (TCC art.1273, para.1), for instance. As for the consideration of YAR by the Turkish courts, an updated version of the rules shall be translated into Turkish by an expert committee and the translation shall be published in the Official Gazette along with the original text of the rules (TCC art.1273, para.2). ${ }^{2}$ Additionally, TCC has placed some supplementary provisions (from art.1272 to art.1285), generally related to the procedure for general average adjustment, to complete the application of YAR in Turkey which will be examined in the following parts of the study.

Components of general average can be counted as follows: common maritime adventure (in which the ship is wholly or partially loaded with cargo), common peril (any danger threatening the ship, cargo, other property and the freight), ${ }^{3}$ extraordinary sacrifice or expenditure (made or incurred for the common safety), intention (even though the 'master' frequently decides whether there is a general average or not, it is not a requirement in

\footnotetext{
${ }^{2}$ As the time of writing, YAR 2016 has not been translated in Turkish by the expert committee and published in the Official Gazette, thus; unless their application is contractually preferred by the parties to contract of affreighthment or bill of lading, the rules shall have no effect as for the Turkish law. However YAR 2016 will soon be translated by the expert committee and for this reason, they have been considered for the explanations on the general average in this study.

${ }^{3}$ The principle of "imminent peril" operates in a wider ambit in circumstances where a danger exists and doing nothing will inevitably require the insurer to respond under the terms of the policy. See Garden View Restaurant Ltd. v. Portage La Prairie Mutual Insurance Co., 2014 CarswellNS 994, 43 C.C.L.I. (5th) 110, 92 C.E.L.R. (3d) 100 Nova Scotia.
} 
accordance with the referred legal text), reasonability (which is the pre-condition for the existence of general average) and beneficial result (in which the ship or the cargo is partially or wholly saved).

General average contribution is defined to be a contribution by all parties in a sea adventure to make good the loss sustained by one of their number due to voluntary sacrifices of part of the ship or cargo to save the remainder and the lives of those on board from an impending peril, or for extraordinary expenses necessarily incurred by one or more of the parties for the general benefit of all the interests embarked in the enterprise [7]. Rights to contribution in general average shall not be affected, though the event which gave rise to the sacrifice or expenditure may have been due to the 'fault' of one of the parties to the common maritime adventure, but this shall not prejudice any remedies or defenses which may be open against or to that party in respect of such fault. ${ }^{4}$

There are three groups of articles in YAR 2016: numbered rules, lettered rules and Rule of Paramount. The Rule of Interpretation which is placed as the first provision of the rules states the line between these rules. According to the rule, except as provided by the Rule Paramount and the numbered Rules, general average shall be adjusted according to the lettered Rules. Thus, the line between the groups of articles placed in YAR 2016 shall be as follows: (1) Rule Paramount ${ }^{5}$ (2) numbered Rules and (3) lettered Rules.

The numbered rules give the examples of the sacrifices that can be included in the general average such as; jettison of cargo (under YAR 2016 I), loss or damage by sacrifice for the common safety (under YAR 2016 II), extinguishing fire on shipboard (under YAR 2016 III), cutting away wreck (under YAR 2016 IV) and voluntary stranding (under YAR $2016 \mathrm{~V})$.

In addition to the above pointed sacrifices, one party may affect payments for the common interest of saving the ship and the cargo such as; salvage remuneration (under YAR 2016 VI), damage to machinery and boilers (under YAR 2016 VII), expenses of lightening a ship when ashore and consequent damage (under YAR 2016 VIII), cargo, ship's materials and stores used for fuel (under YAR 2016 IX), expenses at port of refuge (under YAR $2016 \mathrm{X}$ ), wages and maintenance of crew and other expenses putting into and at a port of refuge (under YAR 2016 XI), damage to cargo in discharging (under YAR 2016 XII), deductions from cost of repairs (under YAR 2016 XIII), temporary repairs (under YAR 2016 XIV), loss of freight (under YAR 2016 XV), amount to be allowed for cargo lost or damaged by sacrifice (under YAR 2016 XVI), contributory values (under YAR 2016 XVII), damage to ship (under YAR 2016 XVIII) and undeclared or wrongfully declared cargo (under YAR 2016 XIX). As per YAR, the above noted expenditures also can be included in the general average.

\subsection{Legal Approach to Collision}

Since the weight and speed of ships have increased, and iron and steel have been used for their construction instead of wood in time, the damage which is suffered as a result of collisions has increased accordingly [8]. Thus, the regulation of collisions, especially under international conventions, has gained more importance.

\footnotetext{
${ }^{4}$ See YAR 2016, Rule D.

${ }^{5}$ In no case shall there be any allowance for sacrifice or expenditure unless reasonably made or incurred (YAR 2016, Rule Paramount).
} 
A crash of two or more ships is called collision. ${ }^{6}$ Components of the collision can be listed as the ship (being a commercial ship is not required) ${ }^{7}$ the crash, and the non-contractual relationship between the crashed ships.

The issue of collision is governed under international conventions, which can be classified as conventions that aim to prevent the occurrence of collision and conventions that govern the liabilities of the parties after collision. The International Convention for the Safety of Life at Sea (London, 01.11.1974; SOLAS) ${ }^{8}$ specifies minimum standards for the construction, equipment and operation of ships, compatible with their safety, and is deemed to be one of the conventions placed under the first classification. In addition, Convention on the International Regulations for Preventing Collisions at Sea (London, 20.10.1972; COLREG) ${ }^{9}$ which recognizes traffic separation schemes and determines safe speeds, the risk of collision and the conduct of ships operating in or near traffic separation schemes, is also deemed to be one of the conventions placed under that classification.

The Convention for the Unification of Certain Rules of Law with respect to Collisions between Vessels (Brussels, 23.09.1910; Collision Convention) ${ }^{10}$ which aims to set certain uniform rules of law with respect to collisions, is deemed to be one of the conventions placed under the second classification. Related articles of this convention have been considered while governing the related articles of TCC on collision (TCC art.1286 to art.1297).

\subsection{Legal Approach to Salvage}

A "salvage service" is a service rendered to a vessel or other marine property in need of assistance. The need for salvage has existed since the time that ships commenced performing voyages at sea [9]. Salvage has been governed under domestic legislations and international conventions. The first attempt to establish a legally mandatory regime governing salvage was the adoption of the Convention for the Unification of Certain Rules of Law respecting Assistance and Salvage at Sea (Brussels, 23.09.1910; Salvage Convention 1910). However as years passed, the convention was not adequate to cover the needs of modern salvage practices. Thus, the International Convention on Salvage (London, 28.04.1989; Salvage Convention 1989) ${ }^{11}$ has been adopted.

Turkey has become a contracting state to both of the above mentioned conventions, and while governing the related articles of TCC on salvage (TCC art.1298 to art.1319), provisions of the latter convention has been considered. Hence Independenta (1979), Nassia (1994), TPAO (1997) and Volgoneft 247 (1999) marine accidents have highlighted the importance of the qualified salvage services, the requirement of prevention of marine pollution, and thus, the codification of salvage in Turkey.

\footnotetext{
${ }^{6}$ The English cases apparently take the view that the term "collision" applies only to the striking together of two navigable ships, and that the term is not applicable to a case where a ship runs into a sunken object. See, Cline v. Western Assur. Co. (1903) 101 Va. 496, 44 S.E. 700, Union Marine Ins. Co. v. Borwick (1895) 64 L. J. Q. B. N. S., Baum v. Girard Fire \& Marine Ins. Co., 228 N.C. 525, 46 S.E.2d 324 (1948).

${ }^{7}$ Unlike the Collision Convention art. 11, warships are also subject to the provisions of TCC governing collision in accordance with TCC art.935, para.2 (b).

${ }^{8}$ Date of Official Gazette: 25.05.1980, Number of Official Gazette: 16985. Turkey is also contracting state to Protocol of 1988 relating to the International Convention for the Safety of life at Sea, 1974.

Date of Official Gazette: 29.05.2013, Number of Official Gazette: 28661.

${ }^{9}$ Date of Official Gazette: 18.11.1984, Number of Official Gazette: 18579.

${ }^{10}$ Date of Official Gazette: 22.02.1955, Number of Official Gazette: 8937.

${ }^{11}$ Date of Official Gazette: 24.05.2014, Number of Official Gazette: 29009.
} 
Components of salvage can be listed as: the activity which is directed to assist a vessel or any other property, ${ }^{12}$ the danger which has the risk of material and economical loss, ${ }^{13}$ the advantageous consequence and the performance of the activity on a volunteering basis.

\section{Comparative Research Between Turkish and International Perspectives}

In this part of the study, Turkish domestic legislation and international conventions that govern marine accidents have been analyzed, comparatively.

\subsection{In terms of General Average}

There is a general average act when, and only when, any extraordinary sacrifice or expenditure is intentionally and reasonably made or incurred for the common safety for the purpose of preserving from peril the property (ship, cargo, other property and freight) involved in a common maritime adventure and only such losses, damages or expenses which are the direct consequence of the general average act shall be allowed as general average (TCC art.1272, para.1). ${ }^{14}$ Any additional expense incurred in place of another expense which would have been allowable as general average shall be deemed to be general average and so allowed without regard to the saving, if any, to other interests, but only up to the amount of the general average expense avoided (TCC art.1272, para.2). ${ }^{15}$

Personal debtors of general average are: the owner of the ship at the time of general average, collector of the freight and owner of the other property at the time of discharge (TCC art.1274, para.1). The consignee of the cargo which is subject to adjustment, shall be personally liable up to the value of that cargo at the time of delivery, and with the rate of adjustment share that shall be found with the liquidation of that cargo in case of nondelivery, provided that he is aware that the cargo was part of the contributing fund during delivery (TCC art.1274, para.2). ${ }^{16}$

Unlike the previous TCC (art.1209) which obliged the 'master' to provide the execution of the adjustment, TCC states that the 'owner' shall provide the execution of the adjustment, without delay (TCC art.1278, para.1). Hence, none of the owners in today's commercial life leave providing the execution of the adjustment to the master. In the breach of this duty, the owner shall be liable to each of the interested persons (TCC art.1278, para.1). When the adjustment is not executed in time, all the interested persons, including the insurer, has the right to demand and provide the execution of it (TCC art.1278, para.2). If the adjustment demand is rejected by the adjuster due to its non-compliance with the features of general average, the court shall decide, upon the demand of each of the interested persons including the insurer, whether the adjustment is required or not (TCC art.1278, para.3). The adjustment shall be executed in the place of arrival. When the ship has not arrived at the place of arrival, the adjustment shall be executed in the place where the voyage has been completed (TCC art. 1279).

\footnotetext{
12 "Property damage", generally defined as injury to or destruction of tangible property, including loss of use. See Garden View Restaurant Ltd. v. Portage La Prairie Mutual Insurance Co., 2014 CarswellNS 994, 43 C.C.L.I. (5th) 110, 92 C.E.L.R. (3d) 100 Nova Scotia.

${ }^{13}$ Therefore, in order to establish a salvage claim, the salvor must establish that the vessel was in marine peril. See American Law Reports, 70 A.L.R. Fed. 2d 251 (Originally published in 2012).

${ }^{14}$ See YAR 2016, Rule A and Rule C

${ }^{15}$ See YAR 2016, Rule F.

${ }^{16}$ YAR Rules 2016, Rule G, para.4.
} 
Adjustment shall be executed by one or more adjusters who have been appointed by consensus of the interested persons. If consensus cannot be reached, the court which will execute the adjustment transactions shall appoint the adjuster(s) (TCC art.1280, para.1). Each of the interested persons shall submit the documents, especially charter parties, bills of lading and invoices that are required for the execution of adjustment (TCC art.1280, para.2). Upon the demand of the adjuster, the court shall order the delivery of these documents which shall be submitted legally (TCC art.1280, para.3). The adjuster shall permit the examination of adjustment by the interested persons and submit one copy of it, provided that these persons cover the costs (TCC art.1280, para.4).

The adjustment report shall consist of four parts as follows: (1) explanation of the general average case, (2) determination of the collectors (owners of the extraordinary sacrifices or expenditures), (3) determination of the debtors (owners of the saved values) and (4) calculation of the adjustment share (total of the extraordinary sacrifice and expenditures - total values ratio) [10].

All the interested persons, including the insurers, have the right to demand the approval of the adjustment report or object to the type of average or average calculations through a petition which shall be submitted to the authorized court noted above (TCC art.1281, para.1). The petition shall include the names and surnames of the interested persons who will be called to the hearings (TCC art.1281, para.2). Upon the submission of the petition, the court shall demand the documents that have force to prove the adjustment and claims from the adjuster or other interested persons (TCC art.1281, para.3). All the interested persons shall be called to the hearings (TCC art.1281, para.4). These persons shall be notified at least 15 days before the hearing (TCC art.1281, para.4). Objections to the adjustment report shall be made explicitly and thoroughly in the first hearing, at the latest (TCC art.1281, para.5). In case of the existence of fair reasons that prevent the submission of the objection on time, the judge shall give sufficient time to the interested person to submit his objection just once (TCC art.1281, para.5). In case of non-submission of the objection, the adjustment report shall be approved (TCC art.1282, para.1). In the case of submission of the objection, it shall be heard and if its fairness is approved by the court, the adjustment report shall be approved through the amendment of the report in accordance with that objection (TCC art.1282, para.1). When the court cannot decide on the objection, all the remaining parts of the adjustment report which are not subject to objection shall be approved by the court, and hearings on the objection shall proceed (TCC art.1282, para.2)

The adjustment report shall have the effect of a court decree with the finalization of the decision on the approval of that report (TCC art.1284, para.1). The same applies to the decision of the court on the adjustment report which has not been subjected to objection (TCC art.1284, para.1). A court decision on the approval of the adjustment report shall have no effect on interested persons who have not been called to the hearings (TCC art.1284, para.2).

Claims arising from a general average adjustment shall be time barred in 1 year (TCC art.1285, para.1). The time bar commences with the arrival of the ship at the place of arrival, or, if she cannot, at the place where the voyage is completed (TCC art.1285, para.2). The provision is the only provision which is in contradiction with the YAR. Hence according to Rule XXIII of YAR, the period of 1 year will commence when the general average adjustment is issued. However, in no case shall such an action be brought after six years from the date of termination of the common maritime adventure.

Table 1 is figured according to the above placed explanations and shows the similar, supplementary and conflicting provisions upon the comparison of provisions governing general average in Turkish legislation and international legislation. 
Table 1: Comparison of Provisions Governing General Average (TCC vs. YAR)

\begin{tabular}{|l|l|l|l|}
\hline $\begin{array}{c}\text { Comparison of Provisions } \\
\text { Governing General } \\
\text { Average (TCC vs. YAR) }\end{array}$ & $\begin{array}{c}\text { Similar } \\
\text { Provisions } \\
\text { averinition of general }\end{array}$ & $\begin{array}{c}\text { Supplementary } \\
\text { Provisions }\end{array}$ & $\begin{array}{c}\text { Conflicting } \\
\text { Provisions }\end{array}$ \\
\hline General average adjustment & TCC art. 1273 & art. & \\
\hline $\begin{array}{l}\text { Determination of personal } \\
\text { debtors of general average }\end{array}$ & $\begin{array}{l}\text { TCC art.1274, } \\
\text { para.2 }\end{array}$ & $\begin{array}{l}\text { TCC art. 1274, } \\
\text { para.1 }\end{array}$ & \\
\hline $\begin{array}{l}\text { Owner's obligation to } \\
\text { execute the adjustment }\end{array}$ & & TCC art.1278 & \\
\hline Appointment of adjusters & & TCC art.1280 & \\
\hline $\begin{array}{l}\text { Approval of the adjustment } \\
\text { report by the authorized } \\
\text { court and objection to the } \\
\text { report }\end{array}$ & & $\begin{array}{l}\text { TCC art.1281 and } \\
\text { art.1282 }\end{array}$ & \\
\hline Time bar & & & TCC art.1285 \\
\hline
\end{tabular}

Source: Author

\subsection{In terms of Collision}

Where a collision occurs between two or more ships, the compensation due for damages caused to the ships or to any things or persons on board thereof shall be settled in accordance with the provisions which are placed under TCC art.1286 to art.1297 (TCC art.1286, para.1). In addition, provisions governing collision shall also be applied when damage which a ship has caused to another ship, or to cargo or persons on board either ship, either by the execution or non-execution of a maneuver or by the non-observance of the regulations, even if no collision had actually taken place (TCC art.1286, para.2). ${ }^{17}$ However if the damage is caused to the coastal facilities, provisions of TCC governing collision shall not be applied. In such cases, provisions governing the liability of the owner for his seamen's and pilots' faults (under TCC art.1062, para.1) shall be applied.

Collision can be classified in terms of the fault of the parties as; faulty collision and faultless collision. If the collision is accidental, if it is caused by force majeure, or if the cause of the collision is left in doubt, the damage shall be borne by those who have suffered it (TCC art. 1287, para.1). ${ }^{18}$ This provision is applicable notwithstanding the fact that the ships, or any one of them, may be at anchor at the time of the accident (TCC art.1287, para.2). Parallel to the Collision Convention art.2, para.2, the Turkish lawmaker admits that this provision shall also be applied when the ships 'otherwise made fast'; however the issue is not explicitly stated under TCC due to the absence of that wording in the original French text. Unless the existence of fault is proved, faultless collision is deemed to exist. Thus, the person who asserts that he has suffered damage due to the fault of the counterparty in collision shall prove that fault.

If the collision is caused by the fault of one of the ships' owners or seamen, ${ }^{19}$ liability to compensate for the damage incurred as a result of collision shall attach to the one which has

\footnotetext{
${ }^{17}$ See Collision Convention art. 13.

${ }^{18}$ See Collision Convention art.2, para.1.

${ }^{19}$ For instance, master's failure to use ship's radar to obtain early warning of risk of collision, after observing ship on near reciprocal course, has been accepted to violate international regulations for preventing collisions at sea. Additionally ship equipped with radar was under duty to use it intelligently and fully, and master or pilot who failed to do so had heavy burden of proving that fault
} 
committed the fault (TCC art.1288). Unlike the related article placed in the Collision Convention which is seeking the fault of the ships; ${ }^{20} \mathrm{TCC}$ art.1288 seeks the fault of ship owners and seamen.

If the collision is caused by the fault of two or more ships' owners or seamen, liability to compensate for the damage incurred as a result of collision shall attach to each owner, in proportion to the degree of their fault (TCC art.1289, para.1). If, having regard to the circumstances, it is not possible to establish the degree of the respective fault, or if it appears that the fault is equal, the liability shall be apportioned equally (TCC art.1289, para.1). ${ }^{21}$ Owners are not severally liable in terms of these compensation demands (TCC art.1289, para.1). However, in respect of damage caused by death or personal injuries, the ships' owners shall be jointly as well as severally liable to third parties (TCC art.1290, para.1). Still, if, having regard to the circumstances, it is not possible to establish the degree of the respective fault, or if it appears that the fault is equal, the liability shall be apportioned equally (TCC art.1290, para.1). Each owner shall be liable to the degree of his fault in the recourse process (TCC art.1290, para.2).

The right of recovery for damage resulting from a collision is not subject to the issuance of any protest or the fulfillment of any other special formality (TCC art.1293). ${ }^{22}$ Any presumption shall not be considered in regard to determination of fault in collision (TCC art.1294). Actions for the recovery of damage shall be time barred after an interval of 2 years from the date of the casualty (TCC art.1297, para.1). ${ }^{23}$ The period within which a recourse case must be instituted for enforcing the right to obtain contribution under TCC art.1289 and 1290, shall be 1 year from the date of payment (TCC art.1297, para.2).

Table 2 is figured according to the above placed explanations and shows the similar, supplementary and conflicting provisions upon the comparison of provisions governing collision in Turkish legislation and international legislation.

Table 2: Comparison of Provisions Governing Collision (TCC vs. Collision Convention)

\begin{tabular}{|l|l|l|l|}
\hline $\begin{array}{l}\text { Comparison of Provisions } \\
\text { Governing Collision (TCC } \\
\text { vs. Collision Convention) }\end{array}$ & \multicolumn{1}{|c|}{$\begin{array}{c}\text { Similar } \\
\text { Provisions }\end{array}$} & $\begin{array}{c}\text { Supplementary } \\
\text { Provisions }\end{array}$ & $\begin{array}{c}\text { Conflicting } \\
\text { Provisions }\end{array}$ \\
\hline Applicable law & $\begin{array}{l}\text { TCC art.1286, } \\
\text { para.2 }\end{array}$ & $\begin{array}{l}\text { TCC art.1287, } \\
\text { para.2 }\end{array}$ \\
\hline Application to "warships" & & $\begin{array}{l}\text { TCC art.935, } \\
\text { para.2 (b) }\end{array}$ \\
\hline Classification of collision & $\begin{array}{l}\text { TCC art. 1287, } \\
\text { para.1 }\end{array}$ & & TCC art.1288 \\
\hline $\begin{array}{l}\text { Seeking the fault of ships" } \\
\text { owners in faulty collision }\end{array}$ & & & \\
\hline $\begin{array}{l}\text { Apportionment of faults } \\
\text { No requirement of any } \\
\text { formal transactions to direct } \\
\text { compensation demand }\end{array}$ & TCC art.1293 & & \\
\hline
\end{tabular}

did not contribute to collision. See Complaint of $G \&$ \& Shipping Co., Ltd. of Anguilla, 767 F.Supp. 398 (1991).

${ }^{20}$ If the collision is caused by the fault of one of the vessels, liability to make good the damages attaches to the one which has committed the fault (Collision Convention, art.3).

${ }^{21}$ See Collision Convention art.4, para.1.

${ }^{22}$ See Collision Convention, art. 6, para.1.

${ }^{23}$ See Collision Convention, art.7, para.1. 


\begin{tabular}{|l|l|l|l|}
\hline Time bar & $\begin{array}{l}\text { TCC art.1297, } \\
\text { para.1 }\end{array}$ & & \\
\hline
\end{tabular}

Source: Author

\subsection{In terms of Salvage}

TCC has placed several provisions with regard to the definition and components of salvage. Most of the provisions are parallel to the Salvage Convention 1989. First of all, 'salvage operation' is defined as any act or activity undertaken to assist a vessel or any other property in danger in navigable waters and is subjected to TCC art.1298 to art.1319 (TCC art.1298, para.1). ${ }^{24}$ 'Vessel' means any ship or craft or any structure capable of navigation (TCC art.1298, para.2). ${ }^{25}$ 'Property' means any property not permanently and intentionally attached to the shoreline and includes freight at risk, other than: (a) fixed or floating platforms or mobile offshore drilling units when such platforms or units are on location engaged in the exploration, exploitation or production of sea-bed mineral resources and (b) prehistorical, archeological or cultural monuments that has historical value on sea-beds (TCC art.1298, para.2 and para.3). Additionally, provisions of TCC governing salvage shall be applied notwithstanding that the salvor has obligation to save under legislation or the salved vessel and the vessel undertaking the salvage operations belong to the same owner (TCC art.1299). These provisions will also be applied to warships (TCC art.935, para.2 (b)). ${ }^{26}$

On the other hand, activities shall not be regarded under the context of salvage activity if they are performed: (a) in contravention of the clear and reasonable deprecation of the owner of the vessel or master or owner of the property or (b) by the persons who are employed on the vessel that is in danger or (c) to fulfill the duties arising from a contract which is signed before the occurrence of the danger (TCC art.1298, para.4).

The master is entitled to conclude contracts for salvage operations on behalf of the owner of the vessel (TCC art.1300, para.1). ${ }^{27}$ In addition, the master or the owner of the vessel is entitled to conclude such contracts on behalf of the owner of the property on board the vessel (TCC art.1300, para.2). ${ }^{28}$ These authorities include determination of the authorized court and arbitration (TCC art.1300, para.2).

Since there are no forms required between the articles of TCC governing salvage contracts for validity; salvage contracts can even be concluded orally. However in international practice, parties of salvage operations frequently prefer to use standard forms of salvage contract such as Lloyd's Standard Form of Salvage Agreement (universally known as Lloyd's Open Form, or LOF) [11].

A contract or any terms thereof may be annulled or modified by the court upon demand if: (a) the contract has been entered into under undue influence or the influence of danger and its terms are inequitable or (b) the reward under the contract is to an excessive degree too large or too small for the services actually rendered (TCC art.1301). ${ }^{29}$ This article is one of the mandatory provisions of TCC governing salvage. Hence parties of a salvage contract cannot act against this article by removing the rights of the parties with regard to annulling

\footnotetext{
${ }^{24}$ See Salvage Convention 1989, art.1, para.1 (a).

${ }^{25}$ See Salvage Convention 1989 art.1, para.1 (b).

${ }^{26}$ Even though the preference of Turkey is against the Salvage Convention 1989 art.4, para.1, the convention has recognized the right of a contracting state to apply the provisions of the convention to warships, provided that Secretary-General has been notified by that state (Salvage Convention 1989 art.4, para.2).

${ }^{27}$ See Salvage Convention 1989, art.6, para.2.

${ }^{28}$ See Salvage Convention 1989, art.6, para.2.

${ }^{29}$ See Salvage Convention 1989 art.7.
} 
or modifying the contract (TCC art.1302, para.2). Another mandatory provision, which cannot be changed by the parties of a salvage contract, governs the obligation of the parties to exercise due care to prevent or minimize damage to the environment set under TCC art. 1303 (TCC art.1302, para.2).

Salvage operations which have had a useful result give right to payment (TCC art.1304, para.1). ${ }^{30}$ Except as otherwise stated under the related articles of TCC governing salvage, no payment is due if the salvage operations have had no useful result (TCC art.1304, para.2). The payments, exclusive of any interest and recoverable legal costs that may be payable thereon, shall not exceed the salved value of the property during the salvage activity (TCC art.1304, para.3).

When the salvage reward is not determined by the parties or the amount which has been determined is claimed to be modified by the court, the reward shall be fixed with a view to encouraging salvage operations, taking into account the following criteria without regard to the order in which they are presented: (a) the salved value of the vessel and other property after salvage activity, (b) the skill and efforts of the salvors in preventing or minimizing damage to the environment, (c) the measure of success obtained by the salvor, (d) the nature and degree of the danger, (e) the skill and efforts of the salvors in salving the vessel, other property and life, (f) the time used and expenses and losses incurred by the salvors, (g) the risk of liability and other risks run by the salvors or their equipment, (h) the promptness of the services rendered, (i) the availability and use of vessels or other equipment intended for salvage operations and $(\mathrm{j})$ the state of readiness and efficiency of the salvor's equipment and the value thereof (TCC art.1305, para.1). Unlike the Salvage Convention 1989 art. 13, the above noted criteria shall only be considered by the Turkish courts when the salvage reward is not determined by the parties, or modification of the amount which has been determined by the parties has been claimed from the court [12].

Expenditure and charges of official institutions, customs taxes and other dues that shall be paid for the salved value and costs incurred for the storage, protection, valuation and sale of these values are not included under the salvage reward (TCC art.1305, para.2). The salvage reward shall be calculated over money. Unless otherwise agreed, the salvage reward shall not be determined as a percentage of the salved value (TCC art.1305, para.3).

The debtors of the salvage reward are the owners of the vessel and other property at the time of salvage activity (TCC art.1306, para.1). The salvage reward shall be paid by all of the vessel and other property interests in proportion to their salved values (TCC art.1306, para.2). Liability of the debtors of the salvage reward shall not be jointly and severally allocated (TCC art.1306, para.2). The consignee, on the other hand, shall be personally liable for the payment of the salvage reward in proportion to the salved value that will be calculated upon the liquidation of that cargo in case of non-delivery, provided that he has knowledge of the payment of salvage reward during delivery of the cargo (TCC art.1307, para.1). When other properties are saved with the delivered cargo, the liability of the consignee for the payment of the salvage reward shall not exceed the amount which will be charged up to the delivered cargo as a proportion of all costs among all property (TCC art.1307, para.2).

A single salvage reward shall be determined for all activities performed during the period, beginning with the danger that leads to the salvage activity until the demand for redelivery of the salved property (TCC art.1308, para.1). All the salvors who demand a proportion of the salvage reward shall take their proportions from that single salvage reward (TCC art.1308, para.1). The apportionment of the salvage reward between salvors shall be made in accordance with the criteria stated under TCC art. 1305 with regard to their attendance to the salvage activity (TCC art.1309).

\footnotetext{
${ }^{30}$ See Salvage Convention 1989 art. 12, para.1.
} 
The apportionment of the salvage reward between the owner, master and other persons in the service of each salving vessel shall be determined by the law of the flag of that vessel (Salvage Convention 1989 art.15, para.2). The Turkish lawmaker has preferred the execution of the apportionment between master and other seamen in accordance with the criteria stated under TCC art.1305, by reserving the amount of damage to the salvor vessel and the costs incurred after the salvage activity (TCC art.1310, para.1). However, when the salvage operation is performed by a ship which is assigned for salvage purposes or by a trailer, seamen who are in the service of these ships cannot demand a proportion of the salvage reward (TCC art.1310, para.5).

Upon the finalization of the salvage activity, the owner shall prepare a 'share table' that indicates the shares of the master and other seamen, and notifies it to these persons (TCC art.1310, para.2). The master and other seamen are entitled to object to this share table in front of the authorized court located in the place of arrival in Turkey within 15 days beginning from the arrival at that port (TCC art.1310, para.3). Upon listening to the interested persons, the court shall approve the share table directly or through amendment (TCC art.1310, para.4). The decision of the court is final (TCC art.1310, para.4). When the salvage activity is performed by a vessel other than a ship, the salvage reward shall be allocated between the salvor and his servants in accordance with the contract between them, and in the absence of this contract, in accordance with the criteria set under TCC art.1305 (TCC art.1310, para.6). Finally, a salvor may be deprived of the whole or part of the salvage reward due to the extent that the salvage operations became necessary or more difficult due to the fault or neglect on his part or if the salvor has been guilty of fraud or performed other dishonest conduct (TCC art.1311). ${ }^{31}$

The right of the salvor to interest on any payment due under the Salvage Convention 1989 shall be determined in accordance with the law of the state in which the tribunal dealing with the case is situated (Salvage Convention 1989 art.24). The Turkish lawmaker has determined to apply interest to all the claims of the salvor beginning from the date of delivery of the salved property, and when the property cannot be delivered, from the date of finalization of the salvage activity in terms of special compensation (TCC art.1313). Upon the request of the salvor, a person liable for salvage reward shall provide satisfactory security for the claim, including interest and judicial costs incurred by the salvor (TCC art.1314). ${ }^{32}$

The salvor has the right of retention on the salved property in accordance with TCivC art.950 to art.953 and the right of maritime lien on the salved vessel (TCC art.1315, para.1). The salvor may not enforce the right of maritime lien when satisfactory security for his claim, has been duly tendered or provided. Hence, the owner of the salved vessel shall use his best endeavors to ensure that the owners of the cargo provide satisfactory security for the claims against them including interest and costs (TCC art.1315, para.2). ${ }^{33}$ The salved vessel and other property shall not, without the consent of the salvor, be removed from the port or place at which they first arrive after the completion of the salvage operations until satisfactory security has been put up for the salvor's claim against the relevant vessel or property (TCC art.1315, para.3) ${ }^{34}$ The tribunal or court having jurisdiction over the claim of the salvor may, by interim decision, order that the salvor shall be paid on account such amount as seems fair and just, and on such terms, including terms as to security where appropriate, as may be fair and just according to the circumstances of the case (TCC

\footnotetext{
${ }^{31}$ See Salvage Convention 1989 art.18.

32 See Salvage Convention 1989 art.21, para.1.

33 See Salvage Convention 1989 art.21, para.2.

${ }^{34}$ See Salvage Convention 1989 art.21, para.3.
} 
art.1316). ${ }^{35}$ In the event of an interim payment, the security provided shall be reduced accordingly (TCC art.1316). ${ }^{36}$

The rule is that salvage operations which have had an advantageous consequence shall reveal the right of salvage reward.$^{37}$ However there is an exception to this rule. Hence, as noted above, the Turkish lawmaker explicitly highlighted that there are exceptions to the rule which states that no payment shall be due if the salvage operations have had no useful result (TCC art.1304, para.2).

The Turkish lawmaker has stated that when the salvor has carried out salvage operations in respect of a ship which by itself or its cargo threatened damage to the environment and has failed to earn a payment under the related provisions at least equivalent to the special compensation assessable in accordance with TCC art.1305, he shall be given special compensation from the owner of that vessel equivalent to his expenses as defined hereunder (TCC art.1312, para.1). ${ }^{38}$ The court or tribunal is under no duty to fix a salvage reward up to the maximum salved value of the vessel and other property before assessing the special compensation to be paid (TCC art.1312, para.1). ${ }^{39}$

If, in the circumstances set out above for special compensation, the salvor by his salvage operations has prevented or minimized damage to the environment, the special compensation payable by the owner to the salvor may be increased up to a maximum of 30 per cent of the expenses incurred by the salvor (TCC art.1312, para.2). ${ }^{40}$ However, the court or the tribunal, if it deems it fair and just to do so and bearing in mind the relevant criteria to determine salvage reward, may increase such special compensation further, but in no event shall the total increase be more than 100 per cent of the expenses incurred by the salvor (TCC art.1312, para.2). ${ }^{41}$

The salvor's expenses for the purpose of the above noted paragraphs means the out-ofpocket expenses reasonably incurred by the salvor in the salvage operation and a fair rate for equipment and personnel actually and reasonably used in the salvage operation, taking into consideration the criteria set out in TCC art. 1305, para. 1 (h), (i) and (j) (TCC art.1312, para.3). The total special compensation under this article shall be paid only if and to the extent that such compensation is greater than any reward recoverable by the salvor under TCC art. 1305 (TCC art.1312, para.4). If the salvor has been negligent and has thereby failed to prevent or minimize damage to the environment, he may be deprived of the whole or part of any special compensation due under this article (TCC art.1312, para.5). Nothing in this article shall affect any right of recourse on the part of the owner of the ship (TCC art.1312, para.6). No payment made under this article is subject to general average adjustment (TCC art.1312, para.7).

Provided that the amount of his reward shall not be prejudiced should it be found that such a request was unreasonable, the salvor shall owe a duty to the owner of the vessel or

\footnotetext{
${ }^{35}$ See Salvage Convention 1989 art.22, para.1.

${ }^{36}$ See Salvage Convention 1989 art.22, para.2.

${ }^{37} \mathrm{An}$ award of salvage is generally appropriate when property is successfully and voluntarily rescued from marine peril. See Sunglory Maritime, Ltd. v. PHI, Inc., 212 F.Supp.3d 618 (2016). In other words, successful salvage claim requires three proofs: (1) marine peril; (2) voluntary service rendered when not required as existing duty or from special contract; and (3) success in whole or in part, or contribution to success of operation. See U.S. v. EX-USS CABOT/DEDALO, 297 F.3d 378 (2002). Finally, to establish a salvage claim, it is not necessary for the claimant to actually complete the work of saving the property; it is sufficient if he endeavors to do so, and his efforts have a causal relation to the property's eventual preservation. See In re Iowa Fleeting Service, Inc., 211 F.Supp.2d 794 (2002).

${ }^{38}$ See Salvage Convention 1989 art. 14, para.1.

${ }^{39}$ See Salvage Convention 1989 Attachment 1.

${ }^{40}$ See Salvage Convention 1989 art.14, para.2.

${ }^{41}$ See Salvage Convention 1989 art.14, para.2.
} 
other property in danger: (a) to carry out the salvage operations with due care, (b) to exercise due care to prevent or minimize damage to the environment, while performing the duty specified in (a), (c) to seek assistance from other salvors, whenever circumstances reasonably require, and (d) to accept the intervention of other salvors, when reasonably requested to do so by the owner or master of the vessel or other property in danger (TCC art.1303, para.1). ${ }^{42}$

The owner and master of the vessel or the owner of other property in danger shall owe a duty to the salvor: (a) to co-operate fully with him during the course of the salvage operations, (b) in so doing, to exercise due care to prevent or minimize damage to the environment, and (c) when the vessel or other property has been brought to a place of safety, to accept delivery when reasonably requested by the salvor to do so (TCC art.1303, para.2). ${ }^{43}$ In the application of the above noted provisions 'damage to the environment' refers to substantial physical damage to human health or to marine life or resources in coastal or inland waters or areas adjacent thereto, caused by pollution, contamination, fire, explosion or similar major incidents (TCC art.1303, para.3). ${ }^{44}$

Every master is bound, so far as he can do so without serious danger to his vessel and persons thereon, to render assistance to any person in danger of being lost at sea (TCC art.1317, para.1). ${ }^{45}$ The owner of the vessel shall incur no liability for a breach of that duty by the master (TCC art.1317, para.2). ${ }^{46}$

According to Salvage Convention 1989, no remuneration is due from persons whose lives are saved (Salvage Convention 1989 art.16). The convention has also recognized the discretion of the contracting states by stating that provisions of domestic law governing salvage reward upon salvage of persons shall not affect the provisions of domestic law on this subject. The Turkish lawmaker has preferred to act in accordance with the related provision of the convention. Thus, no remuneration is due from persons whose lives are saved in terms of Turkish law (TCC art.1318, para.1). On the other hand, a salvor of human life, who has taken part in the services rendered on the occasion of the accident giving rise to salvage, is entitled to a fair share of the payment awarded to the salvor for salving the vessel or other property or preventing or minimizing damage to the environment (TCC art.1318, para.2) ${ }^{47}$

Any case relating to salvage reward payment shall be time-barred if judicial or arbitral proceedings have not been instituted within a period of 2 years (TCC art.1319, para.1). ${ }^{48}$ The limitation period commences on the day on which the salvage operations are terminated (TCC art.1319, para.2). ${ }^{49}$ The person against whom a claim is made may at any time during the running of the limitation period extend that period by a declaration to the claimant for several times (TCC art.1319, para.3).

Table 3 is figured according to the above placed explanations and shows the similar, supplementary and conflicting provisions upon the comparison of provisions governing salvage in Turkish legislation and international legislation.

\footnotetext{
${ }^{42}$ See Salvage Convention 1989 art.8, para.1.

${ }^{43}$ See Salvage Convention 1989 art.8, para.2.

${ }^{44}$ See Salvage Convention 1989 art.1, para.1 (d).

${ }^{45}$ See Salvage Convention 1989 art.10, para.1.

${ }^{46}$ See Salvage Convention 1989 art.10, para.3.

${ }^{47}$ See Salvage Convention 1989 art.16, para.2.

${ }^{48}$ See Salvage Convention 1989 art.23, para.1.

${ }^{49}$ See Salvage Convention 1989 art.23, para.1.
} 
Table 3: Comparison of Provisions Governing Salvage (TCC vs. Salvage Convention 1989)

\begin{tabular}{|c|c|c|c|}
\hline $\begin{array}{c}\text { Comparison of Provisions } \\
\text { Governing Salvage (TCC } \\
\text { vs. Salvage Convention } \\
\text { 1989) }\end{array}$ & Similar Provisions & $\begin{array}{c}\text { Supplementary } \\
\text { Provisions }\end{array}$ & $\begin{array}{l}\text { Conflicting } \\
\text { Provisions }\end{array}$ \\
\hline $\begin{array}{l}\text { Definition of "salvage } \\
\text { operation" and "vessel" }\end{array}$ & TCC art.1298 & & \\
\hline Application to "warships" & & $\begin{array}{l}\text { TCC art. } 935, \\
\text { para. } 2(b)\end{array}$ & \\
\hline $\begin{array}{l}\text { Master's authority to } \\
\text { conclude contracts of } \\
\text { salvage }\end{array}$ & $\begin{array}{l}\text { TCC art.1300, } \\
\text { para. } 1\end{array}$ & & \\
\hline $\begin{array}{l}\text { Annulment or modification } \\
\text { of salvage contract }\end{array}$ & TCC art.1301 & $\begin{array}{l}\text { TCC art.1302, } \\
\text { para. } 2\end{array}$ & \\
\hline Salvage reward & $\begin{array}{l}\text { TCC art.1304, } \\
\text { para.1 }\end{array}$ & & \\
\hline $\begin{array}{l}\text { Consideration of the criteria } \\
\text { in determining the amount } \\
\text { of salvage reward }\end{array}$ & & & $\begin{array}{l}\text { TCC art.1305, } \\
\text { para. } 1\end{array}$ \\
\hline $\begin{array}{l}\text { Debtors of the salvage } \\
\text { reward }\end{array}$ & & $\begin{array}{l}\text { TCC art.1306, } \\
\text { para. } 1\end{array}$ & \\
\hline $\begin{array}{l}\text { Execution of the } \\
\text { apportionment between } \\
\text { master and other seamen }\end{array}$ & & $\begin{array}{l}\text { TCC art.1310, } \\
\text { para. } 1\end{array}$ & \\
\hline Interest on any payment & & TCC art.1313 & \\
\hline $\begin{array}{l}\text { Providing security to collect } \\
\text { salvage reward }\end{array}$ & TCC art.1315 & & \\
\hline Special compensation & $\begin{array}{l}\text { TCC art.1312, } \\
\text { para.1 }\end{array}$ & & \\
\hline $\begin{array}{l}\text { Duties of the salvor and } \\
\text { owner of the vessel or other } \\
\text { property in danger }\end{array}$ & $\begin{array}{l}\text { TCC art.1303, } \\
\text { para. } 1\end{array}$ & & \\
\hline Salvage of human life & & $\begin{array}{l}\text { TCC art.1318, } \\
\text { para. } 1\end{array}$ & \\
\hline Time bar & TCC art.1319 & & \\
\hline
\end{tabular}

Source: Author

\section{Conclusions}

The occurrence and effects of marine accidents carry intensive international characteristics. Accordingly, ensuring international uniformity on the legal approach to marine accidents is important. Hence when it is achieved, the courts of the different states are expected to give nearly the same decision on the same conflict. If the effect of uniformity is assumed to be a 'chain' consisting of three rings, the first ring of the chain will be 'predictability' that originates from the parties' knowledge of the consequences of their acts; the second ring of the chain will be 'reliability' that is a consequence of a predictable liability regime; and the last ring of the chain will be 'continuance' that is supported by reliable and secure relationships.

In the study the main topics of marine accidents such as; general average, collision and salvage have been analyzed in terms of their general aspects and their regulation under 
domestic and international approaches. Thus the achievement of ensuring uniformity in the legal approach to marine accidents for Turkish application is tried to be figured out.

As a consequence, it has been found out that Turkey is following the updated legal developments on the issues by considering the international regulations governing marine accidents and referring to their applications explicitly or adapting the related articles of them in its domestic regulations. However, upon the examination of the above placed three tables, it is clear that Turkish lawmaker has placed some provisions other than the ones placed in these international regulations, especially while governing the procedural issues and applicability of the articles. There would be no concern if these provisions only had supplied the gaps of the international conventions (such as determination of personal debtors of general average; owner's obligation to execute the adjustment; appointment of adjusters; approval of the adjustment report or objection to it; annulment or modification of the salvage contract; debtors of the salvage reward; execution of the apportionment between master and other seamen; interest on any payment or salvage of human right) or if such provisions are only governing procedural issues (such as consideration of the criteria in determining the amount of salvage reward). However especially in terms of collision, number of provisions governing the essentials of the issue and placed under Collision Convention and TCC are conflicting in terms of applicability and liability. This may arise as a result of the outdated feature of the convention. Whatever the reason is, it is obvious that these conflicts will damage the aim of ensuring international uniformity in the area. Additionally, the difference in between the provisions governing time-bar in YAK and TCC may cause the same problem even though YAK is not an international convention but has been referred to in all standard forms of contracts of affreightment.

\section{References}

1. Zhiwei, Z., Xiao-Ming, L., Nat. Hazards Earth Syst. Sci. 17, 2041 (2017).

2. Faulkner, D., Proceedings- Institute of Marine Engineering Science and Technology Part B Journal of Marine Design and Operations 5, 37 (2004).

3. Ugurlu, O., International Journal of Industrial Ergonomics 55, 11 (2016).

4. Meifeng, L., Sung-Ho, S., Young-Tae, C., Maritime Policy \& Management 44, 603 (2017).

5. Kendall, W. R., Boykin, N. H., Nathan A., Transportation Journal 50, 219 (2011).

6. Felicia, S., Constanta Maritime University's Annals 18, 349 (2013).

7. Kendall, Boykin, Heller, 219.

8. Kender, R., Çetingil, E ., Yazıcıoğlu, E, Deniz Ticareti Hukuku (Temel Bilgiler) (14 ${ }^{\text {th }}$ Edition, Istanbul 2014, p. 281).

9. Kender, Çetingil, Yazıcıŏlu, p. 293.

10. Kender, Çetingil, Yazıcıoğlu, p. 278.

11. Gaskell, N.J.J., Tul. Mar. L.J. 16, 7 (1991).

12. Kula Degirmenci, N. Maritime Law in Turkey (Istanbul 2017).

Court Decisions

Baum v. Girard Fire \& Marine Ins. Co., 228 N.C. 525, 46 S.E.2d 324 (1948).

Cline v. Western Assur. Co. (1903) 101 Va. 496, 44 S.E. 700.

Complaint of G \& G Shipping Co., Ltd. of Anguilla, 767 F.Supp. 398 (1991).

Garden View Restaurant Ltd. v. Portage La Prairie Mutual Insurance Co., 2014 CarswellNS 994, 43 C.C.L.I. (5th) 110, 92 C.E.L.R. (3d) 100 Nova Scotia.

In re Iowa Fleeting Service, Inc., 211 F.Supp.2d 794 (2002).

Mitsui \& Co Ltd v Beteiligungsgesellschaft LPG Tankerflotte, 2017 WL 04792011.

Sunglory Maritime, Ltd. v. PHI, Inc., 212 F.Supp.3d 618 (2016)

Union Marine Ins. Co. v. Borwick (1895) 64 L. J. Q. B. N. S..

U.S. v. EX-USS CABOT/DEDALO, 297 F.3d 378 (2002). 